\title{
Re-assertion of Elite Control in Masoka's Wildlife Program, Zimbabwe
}

\author{
Shylock Muyengwa ${ }^{1} \&$ Brian Child ${ }^{2}$ \\ ${ }^{1}$ School of Natural Resources, Univeristy of Florida, USA \\ ${ }^{2}$ Department of Geography, University of Florida, USA \\ Correspondence: Shylock Muyengwa. 15 Ridge Road Avondale Harare, Zimbabwe. \\ shylock.muyengwa@gmail.com
}

Received: April 9, $2017 \quad$ Accepted: July 5, $2017 \quad$ Online Published: November 29, 2017

doi:10.5539/jsd.v10n6p28 URL: https://doi.org/10.5539/jsd.v10n6p28

\begin{abstract}
Local level governance is crucial in delivering benefits of conservation to communities. This paper provides a historical review of the evolution of governance and the emergence of elite capture in Masoka's wildlife program in Zimbabwe between 2009 and 2011. Fifty-four key informant interviews and reviews of numerous secondary data sources analyzed in order to understand accountability mechanisms, collective decision-making, and the allocation of wildlife revenues into various local initiatives. The local narratives and secondary data suggested that the governance had flipped from one of impersonal and democratic rule to one based on personal rule of traditional leaders. These outcomes were in part a result of the shift in meso level structures that previously supported the program structures at community level, the shifting national politics that led to increased sense of enfranchisement and impunity among traditional leaders, and non-merit based system of appointing committee members. The results suggest that locally elected committees when left at the peril of strong and unchecked powers of traditional leaders they are bound to collapse. Second, the findings also indicate that in the absence of weak land tenure rights, locals have no "teeth" to challenge tradition-based authorities in order to demand for accountable governance. We conclude that given such condition of weak tenure and access to resource rights, local democratic institutions do not emerge naturally even if most people want them and if not protected from outside, they are bound to fail and superseded by personalized ones.
\end{abstract}

Keywords: governance, elite capture, democracy, impersonal governance, institutionalized rule

\section{Introduction}

Masoka's Wildlife Management program was considered a robust and successful case of a local wildlife managing community in Zimbabwe judged by data (e.g. high wildlife populations, increased income to community, and relatively high number of community funded projects) (N. Nabane and Matzke, 1997; Matzke and Nabane, 1996). The retrospective opinions of people interviewed between 2007 and 2009 (Taylor and Murphree, 2007a; Taylor, 2009) also indicated that Masoka was a successful Communal Areas Management Program for Indigenous Resources (CAMPFIRE) project managed through an impersonal and institutionalized governance system that delivered development and cash benefits to its members(Murombedzi, 1997; Taylor, 2007). However, between 2009 and 2011 it lost its impersonal and institutionalized rule as the elite centralized the governance of CAMPFIRE benefits. The exertion of elite control that occurred in Masoka is a common feature of nascent local level democratic CBNRM institutions. This paper explores how and why these changes took place in Masoka between 2009 and 2011 in order to understand the complex interactions among the elite and non-elite in the allocation of resources.

The changes in Masoka can be best described with the concept of personal rule, informal and formal rules (Acemoglu et al., 2003; Bretton, 1966; Jackson and Rosberg, 1984). Personal rule fosters trust in individuals rather than institutions. Within a personalized systems, big-men allocate resources based on their will and personal procedures (Daron Acemoglu et al., 2004; Williamson, 2000; Jackson and Rosberg, 1984). The later years of CAMPFIRE show that rules shifted to serve the needs of gatekeepers. On the other hand, the relative success of the first phase of the program demonstrates how formal rules build more inclusive and efficient governance. CAMPFIRE reforms in the initial years devolved rights to wildlife to communities and created highly participatory arenas for important collective functions such as quota setting and revenue distribution. The 
highly impersonal system improved the flow of public goods in CAMPFIRE communities including equitable benefit sharing and participation. Institutional reforms consist of improved local rules for managing wildlife resources and incomes, the protection of these reforms through higher level political institutions, and the monitoring and enforcement of these rules (North, 2003). In this case, it refers formal and informal monitoring of adherence to the "CAMPFIRE Principles".

This paper shows how institutional reforms increased the flow of public benefits, but the elite later reversed these reforms into a personalized system. In addition, we view institutions as “... consisting of cognitive, normative, and regulative structures and activities that provide stability and meaning to social behavior." Scott (1995:33). The cognitive and normative view of institutions provides a framework for interpreting local perceptions of the local governance processes. While macro level changes affected the performance of the CAMPFIRE, local narratives focused on micro explanations of institutional failure.

This paper seeks to answer the question whether the case of Masoka provides empirical evidence that inclusive local regimes of participatory governance (as designed by CAMPFIRE) promote multi-dimensional development (i.e. income and voice) compared to more centralized (at local level) regimes? The second undertaking is to interrogate why Masoka 'declined' in the latter period of CAMPFIRE. Local narratives are used to interrogate people's perceptions and the lack of collective action (Olson and Olson, 1965) aimed at replacing a personalized system with a more inclusive and democratic institution. In what follows, we discuss briefly the origins of CAMPFIRE in Masoka and immediately focus on the social and political processes in CAMPFIRE governance and then focus on the local narratives gathered between 2009 and 2011 in order to explore local governance processes.

The study uses historical process tracing and a deductive inquiry case-design approach to understand the governance changes that occurred in Masoka. (Beck, 2006; Bryman et al., 2008; George and Bennett, 2005). We conducted fifty-four open-ended interviews with committee members, Masoka employees, traditional and religious leaders and interacted extensively with local community members. We complemented our discussions with trace data-i.e. minutes and documents kept at the Masoka offices and conducted informal group discussions.

\section{Theoretical Framework}

Good governance of local community projects has been a major theme among development practitioners and the concept of elite capture has attracted attention and debate over how it both affects the performance of projects and how to design projects in ways that minimize the negative impact of the elite on social investments(Dasgupta and Beard, 2007; Fritzen, 2007). The concept of elite capture is defined as “... the capture of the distribution of resources, project implementation and decision making which negatively impacts non-elites or the target population or is deemed to be corrupt under the law" (Musgrave and Wong, 2016) broadly represents the phenomenon that took place in Masoka. In order to find ways of working with elite within community driven develop projects, the two main perspectives are that either the elite are co-opted or countered in order to shape the project outcomes (Wong, 2010). The story is rather complex as empirical evidence suggest that both the elite, and non-elite rely on multiple factors to bargain for power and control.

Community based natural resources management (CBNRM) entails that (a) communities are empowered to manage and benefit from natural resources through leasing of concessions, (b) the revenues that accrue are deposited in a local account, and (c) communities make choices over how this money is allocated through elected decision-making bodies. In most cases, both the elected and non-elected local elites decide how money is spent on a yearly basis or specific time. CBNRM thus, is about the devolution of power and ensuring that communities benefit (Araujo et al., 2005; Iversen et al., 2006; Saito-Jensen et al., 2010). A number of CBNRM programs were crafted in southern Africa's wildlife sector; in Botswana, Mozambique, Namibia, Zambia, and Zimbabwe. In Botswana for example, small communities manage funds up to USD 300, 000 per year (Rihoy and Maguranyanga, 2007) and decide how this money is spent annually. There are local level decision-making frameworks that include quarterly meetings and a premier annual general meeting. The same structure exists in other countries. These cases provide a routine decision making framework that can be used to evaluate whether a small group usually controls decisions and benefit more from these programs-it eliminates Non-Governmental Organizations and State interference. Elites in these communities include elected board members, employees to some extent, and non-elected traditional authorities such as chiefs and religious leaders.

Our case study demonstrates the complex interactions among the elite and non-elite and the various mechanisms used by the elite to control the flow of resources in their favor within a CBNRM project. The primary goal of this paper thus, is to illustrate how the changing macro and meso levels can serve as cues for the elite to capture community projects. Previous studies show how national political process contribute to the decline in local level 
governance but do not provide specific mechanisms that enabled local elites to destroy local level participatory processes (Mapedza and Bond, 2006; Mashinya, 2007; Rihoy et al., 2007). We seek to explore this power dynamic in a more nuanced way. The rest of the paper is organized as follows: a) we provide an historical perspective of the CAMPFIRE, b) the development of CAMPFIRE in Masoka, c) discuss the main findings, c) discussion, and d) the conclusion.

\section{Literature Review}

\subsection{History of the CAMPFIRE Program}

Zimbabwe is one of the places where CBNRM originated through the Wildlife Industries New Development for All (WINDFALL- 1978) and CAMPFIRE (1982) programs that sought to reverse the loss of wildlife on private and communal lands. Zimbabwe introduced new legislation in 1960, and boldly the 1975 Parks and Wildlife Act that devolved the rights to use and benefit from wildlife to private landholders and encouraged the diversification of profitable commercial uses of wildlife. Once the country stabilized in 1980, wildlife rapidly became an important form of land use as terms of trade and economic incentives increasingly favored tourism and hunting relative to livestock and agriculture commodities. In 1982, the government modified the Parks and Wildlife Act and devolved user rights to communal communities. However, legally, the lowest formal institution in communal lands was the Rural District Council (RDC), formed through the Local Government Act. To bridge this gap between policy, intent of wildlife officials, and the existing organizational structure of the Ministry of Local Government and Rural Development, a strategic compromise was reached and Appropriate Authority was devolved to District Councils with a gentleman's agreement that this be further devolved to wildlife "producer communities" (Taylor, 2009; Campbell et al., 2001; B. Child, 1996a) . The CAMPFIRE document then set out a policy of replicating the successes of private conservation in communal lands by devolving proprietorship of wildlife to small communities formed on a voluntary basis (Martin, 1984, 1986).

The CAMPFIRE program partially decentralized the power to manage natural resources to local authorities, which then passed it to locally elected committees. In essence, CAMPFIRE democratized wildlife governance by moving the authority from central state and traditional leaders to formalized constituted institutions. In seeking to avoid creating parallel local institutions, the government vested these rights in the Village Development Committees (VIDCO's) and Ward Development Committees (WADCO's) as substructures of the Rural District Council (RDC). CAMPFIRE empowered VIDCOs and WADCO's relative to the traditional systems of chiefs, headmen and village heads. However, the development committees remained sub-structures of the RDC instead of community jurisdictions in their own right as the Department of National Parks and Wildlife Management (DNPWLM) hoped (Murphree, 1996). These changes often led to challenges as the newly created democratic institutions often struggled against the informal and norm based traditions, especially when communities have weak rights over land and natural resources (Ribot, 2007). The partial devolution resulted in communities with weak rights and limited power in managing the wildlife but they only retained the rights to manage funds and not the wildlife (Songorwa, 1999).

CAMPFIRE required that the RDC and communities collectively manage wildlife resources. The first step was to generate revenues. The primary mechanism for achieving this was to sub-contract hunting and tourism concession to private outfitters in arrangements called joint ventures. DNPWLM passed the authority for negotiating these to the RDCs and producer communities. This helped drive up their value by building the capacity of communities to sell them through open, competitive and transparent arrangements which quadrupled the value of wildlife (Child and Weaver, 2004), but also led to communities getting roughly $33-40 \%$ of the gross turnover that safari outfitters received. Policy makers considered the rest a 'fair' return on the costs of marketing, outfitting, and the capital investment of running high-end safaris. Transparency was enhanced by having the outfitters pay trophy fees or a percentage of gross turnover in US\$ so the communities could share the rapid exchange rate gains associated with the weakening Zimbabwe dollar. The second stage was to organize communities to "spend" money in ways that entrenched participatory face-to-face democracy and accountability in order to maximize the public goods, equitable benefit sharing, and informed participation.

In 1989, the Parks and Wildlife Authority granted Appropriate Authority (AA) to two districts (Nyaminyami and Guruve) and thereafter to ten districts with a potential for wildlife businesses. The work in Nyaminyami provided much of the initial drive to the CAMPFIRE program, but over-capitalization and over-centralization meant that Nyaminyami did not perform well and paradoxically failed to conform to the CAMPFIRE principles (Murombedzi, 1992). The proponents of Nyaminyami were Department of Parks and Wildlife Management (DNPWLM) which was seeking to encourage wildlife conservation in the face of rapid in-migration and land clearance and Save-the- Children who saw the income from wildlife as a means of combatting poverty 
(Murphree and Metcalfe, 1997). These local level initiatives led to the development of other CAMPFIRE programs such as the one that emerged in Masoka.

\subsection{Development of CAMPFIRE in Masoka}

During the early days of CAMPFIRE, Marshall Murphree and the Center for Applied Social Studies at the University of Zimbabwe were working in the mid-Zambezi Valley and became concerned that a top-down donor-funded project to settle the Zambezi Valley (the Mid-Zambezi Valley Resettlement Project) (Derman, 1993, 1987) was doing local people harm. The plans ignored the fact that people already lived there and seemed naïve of the ecological realities of this hot, dry, and infertile region. They began to work closely with the wildlife agency and advocated the devolution of CAMPFIRE revenues to producer communities as a means of promoting local economic and political empowerment and combatting top-down blueprint land use planning with bottom-up participatory development. This argument gained considerable traction with the wildlife agency, which promoted ideals that included local self-determination and preferred adaptive management to blueprint planning in stochastic and non-linear social ecological systems.

Masoka refers to the people of Dande Area, that settled in the area under chief Chisunga (Murombedzi, 1997). Masoka lies in Mbire District (formerly Lower Guruve) in the Zambezi valley in Zimbabwe. It is inhabited by different ethnic groups: Korekore (majority), Karanga (immigrants) and Tembomvura (minority) with a total population of approximately 2,348 (Sicilia, n.d.). Masoka is rich in wildlife but is underdeveloped (Sicilia, n.d.). Local farmers practice small scale agriculture and lack draught power due to tsetse (Taylor and Murphree, 2007). Cotton and maize are major crops in the area. Low rainfall $(\sim 600 \mathrm{~mm})$ and lack of draught power limit extensive agriculture and this provided an impetus for adopting CAMPFIRE as alternate land use model. Locally, an important catalyst in Masoka was an emerging partnership with World Wide Fund for Nature (WW F). The first important activity combined land use planning with a new electric fence so that the people of Masoka centralized themselves in order to protect their crops from elephants and other animals. Revenues began to flow to the community from its abundant wildlife, especially after they replaced their hunter by outsourcing hunting competitively to a joint venture partner. While the process for revenue allocation was not as formally structured as the 'revenue distribution processes' developed in Beitbridge and Mahenye (Brian Child, 1996a), it was nonetheless highly participatory.

Despite the post 2000 turmoil in Zimbabwe, reports on Masoka remained positive, because it managed to implement projects and negotiate for increased revenue share with RDC(Taylor and Murphree, 2007; B. Child, 1996b; Murombedzi, 1999). In 2006, Masoka, alarmed at its loss of revenue to the RDC, allied with the CAMPFIRE Association to renegotiate this position with the council. Masoka claimed that since the wildlife lived on their land are entitled to a fair share of the revenue, and if they did not they would no longer conserve it. The result was a countrywide agreement that hunters automatically and immediately pay half of their fees to producer communities (Jonga, 2006).

Despite these positive stories, there were indications that all was not all was well in Masoka. A number of events had occurred that ran counter to the initial principles. These included: the collapse of the electric fence, the loss of careful honest leadership provided by Headman Kanyurira with his death, and there were other signs of decline, both in local attitudes but also in the retention of more revenue by the Rural District Council (RDC). The value of hunting was further depreciating due to the collapse of the Zimbabwe dollar.

In the following section, we present the study findings, which illustrate how the first phase of the Masoka program was highly participatory, with clearly defined rules and delivered benefits to community members. In the later years, the elite captured most of the program benefits. The last section presents an analysis of some of the factors that led to the changes reported in this study.

\section{Results}

\subsection{Masoka's CAMPFIRE Program Pre - 2009}

As discussed above, Marshall Murphree and the Center for Applied Social Studies (CASS) were instrumental in the founding of the Masoka CAMPFIRE program. The adoption of CAMPFIRE not only redefined natural resources governance, but also created new opportunities for Masoka residents, including hitherto marginalized women (Nabane and Matzke, 1997). For example, the community used CAMPFIRE revenues to build infrastructure and purchase supplementary food during times of drought (see Table 1 for a list of projects and Table 2 for a list of important events ). In addition, it also provided jobs (game guards, fence minders, hunting industry) and paid committee positions. CAMPFIRE also introduced an open and highly participatory system that allowed women to participate in village affairs. Compared to other communities in many ways Masoka was 
an ideal CAMPFIRE site that was not perfect but met all prerequisite conditions for a successful CAMPFIRE community: participatory governance, benefit sharing, and responsible wildlife and asset management(Brian Child, 1996b)

With the adoption of CAMPFIRE in Masoka, the benefits began to flow. The community vastly upgraded the school in an investment considered important by the community and employed fence minders to maintain the electric fence. World Wildlife Fund (WWF) played an important role in building this technical capacity, as well as institutional capacity in the committee to manage the fence and other issues. The community began to manage its wildlife with increasing capacity. With training from WWF, it monitored hunting off-takes, set quotas, counted its wildlife and managed fire. Masoka community performed relatively well compared to other communities. All the incomes that reached Masoka was spent largely on community benefits (Taylor, 2009). These included cash, drought food relief, several key projects (school, clinic), and the employment of fence minders and wildlife monitors. Masoka was doing well.

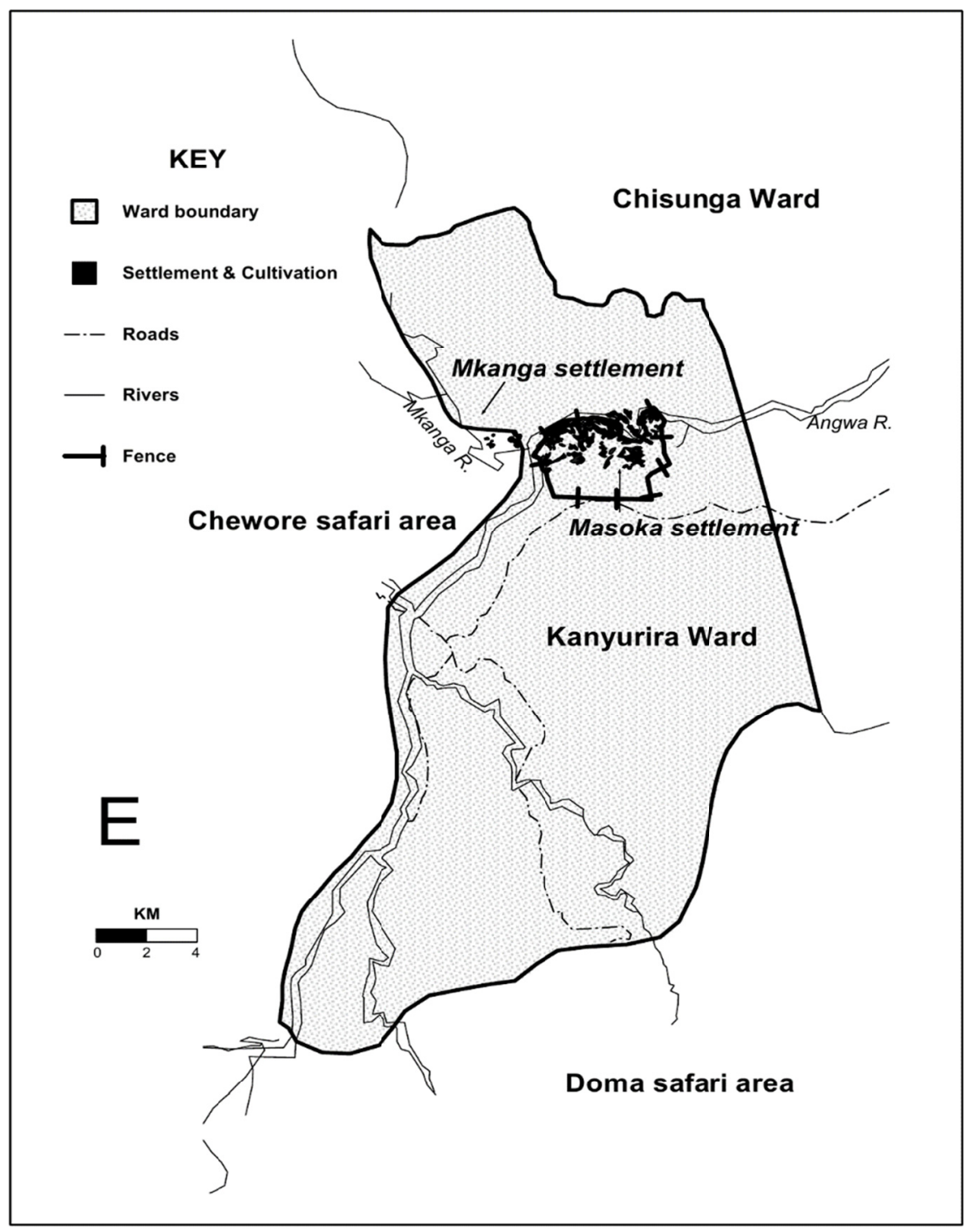

Figure 1. Map of Masoka Community. Adapted from Murphree and Taylor 2007 
Table 1. CAMPFIRE projects

\begin{tabular}{ll}
\hline Project & Year \\
\hline Primary School (4 Blocks) & 1989 \\
Secondary School (2 Blocks) & $1990-1995$ \\
Dividends & 1996 \\
Clinic & 1996 \\
Secondary school & 1998 \\
Tractor & 2005 \\
Truck & 2007 \\
Employment & 6 Game scouts , 6 Guards, 2 teachers, 1 nurse \\
& aid, 1 pump minder, 2 drivers, 3 clerks \\
\hline
\end{tabular}

Source: (R. D. Taylor and Murphree, 2007)

Table 2. Important events in Masoka

\begin{tabular}{ll}
\hline Important Events & Year \\
\hline First Income & 1989 \\
Electric fence constructed & 1990 \\
First settlements outside the fence & 1997 \\
Death of Headman Kanyurira & 2001 \\
Fence collapses & 2003 \\
Confrontation with RDC (Get 50\% income ) & 2006 \\
New Headman & 2006 \\
Direct payment system from Safari Operators & 2007 \\
\hline
\end{tabular}

Source: (R. D. Taylor and Murphree, 2007)

\subsection{Masoka's CAMPFIRE Program 2009-2011}

While the voluntary relocation of people to move inside the fence in 1990 to pave way for wildlife had signaled a strong community support for the CAMPFIRE program ( Hughes, 2001) by 2003 all was not well. The respected, influential, and modest Headman Kanyurira had died. The community was no longer maintaining the fence. In-migration to the area was obvious along the access road to Masoka, and even in Masoka, there were now higher numbers of people living outside the previously fenced area. People expressed unhappiness with the program, and asked that the light-touch facilitators like WWF and Murphree to help them again.

This section describes the situation in between 2009 and 2011 based on field interviews and a review of minutes of meetings held during the period. We interviewed fifty-four people that include the Chief, Headmen, former CAMPFIRE committee members, ordinary villagers, religious leaders and employees. The results showed respondents were concerned with the following: (a) the committee no longer handled finances transparently; (b) CAMPFIRE assets were personalized (c) the committee was allocating CAMPFIRE revenues to the Chief, Headmen, and less to community projects, and (d) there was poor regarding the management of community funds (collapse of the participatory planning process). We discuss these concerns in detail below.

\subsection{Non-Transparent Management of Funds/Indirect Impacts of the Direct Payment System}

The mismanagement of CAMPFIRE funds dominated the local narrative as it deviated from the relatively well functioning system established around 1989. In the initial phases, Masoka community planned collectively with the support of WWF who capacitated committees to manage finance and collective formulation of budgets. Collective planning and budgeting was possible because at the time, the outfitter would pay the RDC large sums of money on an annual basis. The RDC would bank this and in the New Year, the community would be informed 
of its share and would sit together to plan how they wanted to allocate it. The RDC then released money to the community. As we noted above, with the meltdown of Zimbabwe's fiscal circumstances, the value of payments depreciated under the forces of rampant inflation and the financially stretched RDCs appropriated an increasing share of the money. Instigated by Masoka, CAMPFIRE Association negotiated a nation-wide change whereby the hunter would immediately pay half of the required payment for each hunt to the producer community directly (i.e. its minimum share), rather than through the RDC. Therefore, instead of communities getting a lump sum payment annually, they now received regular payments throughout the hunting season.

Interviews around 2011 showed that was no longer the case. The changes from an indirect to direct payment system were not followed by a shift in governance. The direct payment required that community members meet regularly to decide how income is spent. However, interviewed community members indicated that there was little to no consultation regarding how committees were spending incomes. Most interviewed community members indicated that they received reports of how committees had spent income but they rarely participated in the budgeting process. With the introduction of the direct payment system communities needed to meet regularly in order to decide how to spend their wildlife income but this did not occur. As one committee member remarked:

"We are getting our money monthly. We cannot make long-term plans. Council is making a these decisions without consulting us. The RDC only informs us after it has made its decisions. ${ }^{1}$... If we get small amounts, we cannot implement anything meaningful."

The statement above shows that the respective committee member did not understand how the direct payment system works and used this as a basis for justifying the lack of projects. Most committee members felt that spending money as it comes limits their ability to implement projects.

Ordinary community members attributed the failure to implement projects to a collapse of participatory democratic processes. As indicated earlier, collective decision-making correlated with significant social and infrastructural investments in Masoka. Planning meetings were important because they allowed community members to understand and vote for important projects. Immediately after the community selected projects, each project received funds for the entire year. Between 2009 and 2011, the committee implemented projects in an ad hoc manner and the state of local infrastructure showed a dearth of funding toward repair and maintenance. For example, the schools, office, and the clinic were dilapidated and the previously maintained roads were in a bad state. In addition, the secretariat did not keep proper records of meetings. When asked why committees no longer held these planning meetings, ordinary members reported that they had no knowledge such meetings were called.

\subsection{Personal Benefits and Shifting Ethos}

Between 2009 and 2011, committees consistently allocated funds for allowances, travel, and per-diems. The culture of allowances contrasts with the "old" system that was largely accountable to community members. In 2009 for example, the committee members paid themselves sitting allowance for 12 meetings, which achieved little except to gobble up money that could have been allocated to buying books and chalk for the school. This prompted a member of the School Development Committee to comment: "We should not prioritize allowances; we need to develop the school."

The opinions of Masoka's political and traditional leaders had also shifted with the popular narrative placing them over and above ordinary community members. They perceived the CAMPFIRE project as a personal project. The local headmen for example, modified community wishes list so that the Safari Operator builds him a house and buys him a car. One of the community members raised an objection noting that CAMPFIRE was a community and not a private project. In response, the local councilor felt those personal benefits were deserved. The Headman remarked; "The wish list includes my vehicle. You should not be astonished because we "should not be same" -traditional leaders and local people are not equal and the program needs to treat us differently. ${ }^{2}$ While locals recollected the initial principles of CAMPFIRE that emphasize equity in distribution of income, local elite had shifted their focus toward personal enrichment plus total disregard for community views.

It is important to understand how and why the elite dominate local projects despite dissent by local community members. That the Chief and the councilor chose to ignore community voices in Masoka is a broader phenomenon that relates to traditional power relations between Chiefs and their subjects in rural African (Eggen, 2011; Ncube, 2011; Russell and Dobson, 2011). In our case study, the Chief dismissed committee members who

\footnotetext{
${ }^{1}$ Interview with Step Coffee, Masoka Wildlife Development Committee (MWDC) secretary, August 2011

${ }^{2}$ Panyaya ye Wish List pane pick up yaHeadman. hazvifanire kukushamisai nokuti hatifanire kufanana. Community members later molded bricks for the house. During my visit, bricks were already piled at his house.
} 
refused to honor his requests because that challenged "his authority." -for example asking him to submit receipts to support his expenditure constituted insubordination. The Chief also dismissed village heads for non-apparent reasons. These village heads, in most cases can assist in regulating the power of the Chief ${ }^{3}$. The power plays entrenched patron-client relationships that eventually usurped bottom up systems of accountability initially developed for CAMPFIRE. Thus, during this period, committee members served the needs of traditional leaders in order to safeguard their positions.

\subsection{Weak Property Rights and Lack of Protection of Democratic Processes}

The inability to overcome elite domination between 2009 and 2011 is a result of weak property rights and the alignment of traditional leaders with the ruling elite. The following transcript illustrates that it is difficult to establish local level democracy where individuals within communities have weak property rights to both land and the share of the wildlife collective. While most of the community members wanted to revert to the original CAMPFIRE principles as espoused by Marshall Murphree, weak tenure and politicization of CAMPFIRE were a major hindrance. Regarding the community's failure to reinstate the CAMPFIRE principles, one respondent noted:

Member A: We need to go back to what we used to do. We need meetings like in the old days with Professor [referring to Prof. Marshall Murphree] ...

Interviewer: Why do you not challenge these things?

Member A: It is the leadership. Some have been in the committee for seven years and they refuse to step down. We are scared because this involves political leaders. People are too clever these days and we need to change ... especially the councilor.

The transcript illustrates two important issues: a) locals' benchmark CAMPFIRE's performance against the principles developed during the time of Marshall Murphree and b) the politicization of CAMPFIRE requires different mechanisms in order to hold leaders accountable. The Headman for example, threatens to evict local voices of dissent. One respondent noted the following regarding village heads; "They are not doing anything. The headman suppresses their voices. If they complain they are threatened with eviction or are asked to leave the area." ${ }^{\prime 4}$ These high levels of intimidation have led to cooptation of other community elite, especially committee members who then account upward to political leaders such as the Chief and Councilor and not to the constituency in order to safeguard their position in the committee.

The transcript goes further to identify the councilor as the source of the problem in Masoka. In 2007, the Environmental Management Act stipulated that local councilors become de-facto chairpersons for all environmental committees. Masoka community initially opposed this decision as it tied local wildlife management issues to political party lines and it represented top-down planning. Post 2007, CAMPFIRE's political role became highly visible in the country and more so in Masoka where the wildlife revenues paid ZANU-PF sitting allowances. In addition, it was a period where politicians acted with impunity. As one participant noted:

The leaders steal CAMPFIRE revenue. Committees label community members as uneducated and troublesome and they should not be involved in CAMPFIRE decisions. ${ }^{5}$

The collapse of democratic processes elevated traditional and religious leaders to manage the affairs of the CAMPFIRE, compared to the period before where they sat as ex-officio members. In 2009 for example, the Headman was involved in the day-to-day running of the program, parked the community truck at his house regardless of a by-law that prohibited this, and often used the truck for his private business. It was only when some community members threatened to burn the truck that he relinquished control. Despite these small victories toward reinstating CAMPFIRE principles, little had changed by 2011 toward restoring collective decision-making.

\subsection{Information Distortion}

In the initial years, the Masoka program meticulously recorded its finances and these records fed into the participatory planning and project implementation (see Taylor and Murphree, 2007). This robust system had

\footnotetext{
${ }^{3}$ Iyesu masabhuku takatombopihwa ma punishment for six months. Hatina kana kumboziva kuti mhosva dzacho ndedzei? [Even us as village heads, we were punished (suspended for 6 months). We were never told what we had done wrong

${ }^{4}$ Interview with OMJK. August 2011

${ }^{5}$ Vakuru vacho ndivo vanenge vachiba mari. Saka vanotsigirana pamwechete nevashandi vavo. Vakasangana pachezvavo unonzwa vanongoti vanhu havana kudzidza, siyanai nawo.
} 
collapsed by 2009, as most members were not aware of the exact incomes that the community received from safari hunting operations. One community member noted:

$$
\begin{aligned}
& \text { "If we look at what happened last year, they spent } \$ 97000 \text { [2010] without building anything. } \\
& \text { Even the workers are not getting their salaries. The new committees are only tasked with } \\
& \text { clearing debts from the old committee..." }
\end{aligned}
$$

The quote above represents a common perception among most of the community members, that the CAMPFIRE program is generating a lot of income but there is little to show for it due to mismanagement. In general, community members reported higher income figures compared to committee members and did not understand the finances well. As indicated earlier, this is partly due to changes in financial payments from an annual payout to monthly deposits had not been accompanied by governance changes. What most people indicated is that compared to the earlier days where finances were presented well (and with the help of the World Wide Fund for Nature).By 2009, the committee kept most of the important financial records such as salaries and other expenses on loose pieces of paper. Without proper documentation, tracking expenditure is difficult but from the existing records, we could establish that a planned conference center had not been built. Breaking down these systems allows the elite to personalize the benefits (Chabal and Daloz, 1999).

\section{Discussion}

Between 2009 and 2011, the Masoka CAMPFIRE program shifted from highly participatory to a personalized program controlled by the elite, mainly the Chief, Headman, Councilor, and the Committee. As a result, Masoka's CAMPFIRE program failed to deliver communal benefits compared to the previous years. Most community members are aware of the collective benefits of the impersonal governance system and felt they could not challenge the status quo. The narratives presented in this paper contrasts with people's sentiments before 2009. Prior to 2009 for example, the Chief, Headman, and spirit mediums "exercised functional responsibilities." (Matzke and Nabane, 1996) and decisions were based on collective consensus (Cutshall, 1989; Matzke and Nabane, 1996; Jonga, 2006; Taylor and Murphree, 2007). From speaking with community members and reviewing archival sources, evidence suggests the dictatorial tendencies of the Headman and the subtle imposition by the Chief, affected locals perception of the CAMPFIRE program. In addition, the personalization of CAMPFIRE benefits has been a commonly observed trend in other CAMPFIRE programs (Mapedza \& Bond, 2006; Rihoy, Chirozva, \& Anstey, 2010). The collapse in governance in Masoka was due to the loss of external protection plus, the culture of impunity, and re-exertion of personalized rule at national and local levels in Zimbabwe post 2000 trumped what the people liked, wanted, and allowed the re-exertion of personalized rule to play out at local level. Table 3 below summarizes these explanatory factors.

Table 3. Key factors for successful devolution vs. elite capture in Masoka

\begin{tabular}{lll}
\hline & $\begin{array}{l}\text { Successful Devolution } \\
1989-2008\end{array}$ & $\begin{array}{l}\text { Elite Capture } \\
2009-2011\end{array}$ \\
\hline CAMPFIRE Principles & & \\
Community adopted a constitution that guided & $\checkmark$ & \\
implementation of CAMPFIRE & $\checkmark$ & $\times$ \\
Conformance Monitoring & $\checkmark$ & $\times$ \\
Light touch facilitation & $\checkmark$ & $\times$ \\
Good leadership - Leaders that bring people together & \\
to make decisions & $\checkmark$ & $\times$ \\
Clearly defined financial systems (book keeping and & $\checkmark$ & $\checkmark$ \\
financial statements) & $\checkmark$ & $\times$ \\
Participatory meetings & $\checkmark$ & \\
Income & $\checkmark$ & \\
Quota setting & & \\
\hline${ }^{6}$ Community member, Zone 7 Masoka August 2011 & &
\end{tabular}




$\begin{array}{lcc}\text { Size of community (Number of people) } & \text { Small } & \text { Large } \\ \text { Right to income } & \checkmark & \times \\ \text { Rules around management of income } & \checkmark & \times\end{array}$

Compiled by authors.

Institutions are key in regulating human interaction and also define incentives that shape societies over time (North, 1993). In order to ensure that CAMPFIRE functioned properly, the CAMPFIRE guiding principles were drawn and adopted as a constitution. The study observed that committees no longer adhered to these principles or the constitution. Some of the reason as members noted include the absence light touch facilitation from CASS and the WWF on issues of good leadership, participation, and financial management and the direct oversight from the Mbire RDC. The locals frequently requested for the assistance of Marshall Murphree in order to restore the guiding principles - an appeal to externals to fix local issues.

The findings presented in this paper indicate that local democratic institutions do not emerge naturally even if most people want then and if not protected from outside, they are bound to fail and superseded by personalized ones. Following the withdrawal of external support to Masoka's program, the elite were able to capture the Masoka wildlife program. Masoka has consistently generated revenue but due to lack of participatory meetings to ensure that all members benefit, it has failed to fund communal projects and repair existing infrastructure. Whilst community members were fully aware of the collapse in CAMPFIRE, they felt disempowered to challenge the traditional leaders, who often threaten to evict them from their land or dismiss them from the CAMPFIRE committee.

Traditional leaders assumed a more active political role in post 2000 Zimbabwe. More importantly, the ZANU PF led government-introduced benefits for the Chiefs that included cars and electrified houses. This led to an increased sense of entitlement; hence, we see the Headmen and other traditional leaders demanding similar benefits from CAMPFIRE. At the time, this ideology was popular ideology within ZANU PF, and was reflected by how the elected councilor saw CAMPFIRE as an opportunity to enrich the elite rather than provide for the greater good. These consequently led to some changes on Masoka's budget, which was required to provide: (a) allowances for the ruling party members (mostly at the ward meetings), (b) allowances for the Chief, (c) headman's allowances, and (d) the councilors' vote.

The changes in Masoka also need to be seen within the context of Masoka's exponentially increasing population, which has grown more than 10 -fold within two decades due to immigration. By 2000 , the total number of households had increased to 380 (Murphree and Mazambani, 2002) leading to increased ethnic diversity with 64 percent of the people in the area now characterized as migrants (Baudron et al., 2011).Without participatory governance and collective planning, it will be difficult to satisfy a diverse community with potentially competing land use options .

CAMPFIRE communities lack clear rights over wildlife (Balint \& Mashinya, 2006; Mutandwa \& Gadzirayi, 2007) and this weakens the ability of communities to deal with corruption and elite capture when it occurs. In Zimbabwe, traditional leaders remain relatively more empowered compared to the community and more specifically because they have authority over communal lands. In some cases, it is also interpreted to mean de facto ownership of all natural resources in communal areas including wildlife. In the context of CAMPFIRE, we highlighted that the Headman threatens to evict village heads that complain over the management of CAMPFIRE revenues. Therefore, a weak policy that disempowers communities will allow elite capture to persist.

The collapse of local democratic governance in Masoka has led to some unintended outcomes. Some locals have resorted to extensive agriculture migrants farm expansively compared to autochthons ( 3.2 hectares compared to 2.2 hectares) (Baudron et al., 2011). The expansion of cropping areas will lead to increased land clearance and human wildlife conflict. Some farmers have introduced cattle in this fragile ecosystem. ${ }^{7}$ The human wildlife conflict in Masoka has also increased reflecting the underlying social conflicts and people's dissatisfaction with elite capture of CAMPFIRE (Matema and Andersson, 2015).

\section{Conclusion}

The paper has demonstrated that in the absence of external monitoring, strong civil society and clearly defined

\footnotetext{
${ }^{7}$ One community member has been keeping their cattle in the area for more than six months at the time of this research. Some community members are also waiting to see the outcomes of this "experiment" before they can bring their own cows. Human wildlife conflict is likely to increase.
} 
tenure, elites can capture easily well-intentioned programs such as CAMPFIRE. The paper has also demonstrated how the shift in governance from an impersonalized system to a personalized one (between 2009 and 2011) led to significant decline in the quality of governance and the ability of CAMPFIRE to deliver communal benefits. The future of CAMPFIRE, and community based conservation programs lie in significant policy shifts in policy that clearly defines the rights of local communities and then creates mechanisms to protect such institutions from predatory elites. The paper also demonstrated that the initial work in supporting democratic governance helped community members understand and challenge, within the means available, the non-consultative processes that prevailed between 2007 and 2009. Masoka community exuded local agency and recollected clearly the positive benefits of democracy and collective participation. Given a supportive macro and meso political context, community members will be able to dislodge the elite monopolizing communal benefits and reinstate the pre-2009 CAMPFIRE.

\section{References}

Acemoglu, D., Robinson, J. A., \& Verdier, T. (2003). Kleptocracy and divide-and-rule: A model of personal rule. National Bureau of Economic Research.

Araujo, M. C., Ferreira, F. H., Lanjouw, P., \& Özler, B. (2005). Local Inequality and Project Choice in a Social Investment Fund. First draft of a work in progress, World Bank, Washington, DC.

Baudron, F., Corbeels, M., Andersson, J. A., Sibanda, M., \& Giller, K. E. (2011). Delineating the drivers of waning wildlife habitat: The predominance of cotton farming on the fringe of protected areas in the Mid-Zambezi Valley, Zimbabwe. Biological Conservation, 144, 1481-1493. http://dx.doi.org/10.1016/j.biocon.2011.01.017

Beck, N. (2006). Is Causal-Process Observation an Oxymoron? Political Analysis, 14, 347-352. http://dx.doi.org/10.1093/pan/mpj015

Bretton, H. L. (1966). The rise and fall of Kwame Nkrumah: a study of personal rule in Africa. Praeger.

Bryman, A., Becker, S., \& Sempik, J. (2008). Quality criteria for quantitative, qualitative and mixed methods research: A view from social policy. International Journal of Social Research Methodology, 11, 261-276.

Campbell, B., Mandondo, A., Nemarundwe, N., Sithole, B., De JonG, W., Luckert, M., \& Matose, F. (2001). Challenges to Proponents of Common Property Recource Systems: Despairing Voices from the Social Forests of Zimbabwe. World Development, 29, 589-600. http://dx.doi.org/10.1016/S0305-750X (00)00114-5

Chabal, P., \& Daloz, J.-P. (1999). Africa Works: Disorder as political instrument (African issues).

Child, B. (1996a). CAMPFIRE in Zimbabwe. Assessing the Sustainability of Uses of Wild Species. IUCN/SSC Occasional Paper 59-78.

Child, B. (1996b). The practice and principles of community-based wildlife management in Zimbabwe: the CAMPFIRE programme. Biodiversity and Conservation, 5, 369-398. http://dx.doi.org/10.1007/BF00051780

Cutshall, C. R. (1989). Masoka/Kanyurira Ward: a socio-economic baseline survey of community households. Centre for Applied Social Science, University of Zimbabwe, Harare.

Daron Acemoglu, Robinson, J. A., \& Verdier, T. (2004). Alfred Marshall Lecture: Kleptocracy and Divide-and-Rule: A Model of Personal Rule. Journal of the European Economic Association, 2, 162-192.

Dasgupta, A., \& Beard, V. A. (2007). Community driven development, collective action and elite capture in Indonesia. Development and Change, 38, 229-249.

Derman, W. (1993). Recreating common property management: Government projects and land use policy in the Mid-Zambezi Valley, Zimbabwe. Centre for Applied Social Sciences, 1-25.

Derman, W. (1987). Prelimiary reflections on Research isses and strategies for a ling term (Five years or more) Study of Common Property and Natural Resources Management with Particular Emphasis upon Zambezi River Basin. Centre for Applied Social Sciences.

Eggen, Ø. yvind. (2011). Chiefs and Everyday Governance: Parallel State Organisations in Malawi. Journal of Southern African Studies, 37, 313-331. http://dx.doi.org/10.1080/03057070.2011.579436

Fritzen, S. A. (2007). Can the design of community-driven development reduce the risk of elite capture? Evidence from Indonesia. World Development, 35, 1359-1375. 
George, A. L., \& Bennett, A. (2005). Case studies and theory development in the social sciences. MIT Press.

Iversen, V., Chhetry, B., Francis, P., Gurung, M., Kafle, G., Pain, A., \& Seeley, J. (2006). High value forests, hidden economies and elite capture: Evidence from forest user groups in Nepal's Terai. Ecological economics, 58, 93-107.

Jackson, R. H., \& Rosberg, C. G. (1984). Personal Rule: Theory and Practice in Africa. Comparative Politics, 16, $421-442$.

Jonga, C. (2006). Addressing Tenure and Rights in Pro-poor Conservation: The Masoka Community Experience. Poverty, Equity and Rights in Conservation-Technical papers and case studies 72-79.

Mapedza, E., \& Bond, I. (2006). Political Deadlock and Devolved Wildlife Management in Zimbabwe: The Case of Nenyunga Ward. The Journal of Environment \& Development, 15, 407-427.

Mashinya, J. (2007). Participation and devolution in Zimbabwe's CAMPFIRE program: findings from local projects in Mahenye and Nyaminyami.

Matzke, G. E., \& Nabane, N. (1996). Outcomes of a community controlled wildlife utilization program in a Zambezi Valley community. Human Ecology, 24, 65-85. http://dx.doi.org/10.1007/BF02167961

McDermott Hughes, D. (2001). Cadastral Politics: The Making of Community-Based Resource Management in Zimbabwe and Mozambique. Development and Change, 32, 741-768.

Murombedzi, J. (1997). Management of the land and resources of the Masoka community of Dande communal lands, Zimbabwe. Society \& Natural Resources, 10, 405-408. http://dx.doi.org/10.1080/08941929709381038

Murombedzi, J. C. (1999). Devolution and stewardship in Zimbabwe's CAMPFIRE programme. Journal of International Development, 11, 287-293. http://dx.doi.org/10.1002/(SICI)1099-1328(199903/04)11:2<287::AID-JID584>3.0.CO;2-M

Murphree, M. W., \& Mazambani, D. (2002). Policy implications of common pool resource knowledge: A background paper on Zimbabwe. Carried out as part of an initiative entitled Policy Implications of Common Pool Resource Knowledge in India, Tanzania and Zimbabwe, UK Department for International Development Natural Resources Programme: Semi-Arid Production Systems (Project R7973) 127.

Murphree, M. W., \& Metcalfe, S. (1997). Conservancy policy and the CAMPFIRE Programme in Zimbabwe. Centre for Applied Social Sciences, University of Zimbabwe.

Musgrave, M. K., \& Wong, S. (2016). Towards a More Nuanced Theory of Elite Capture in Development Projects. The Importance of Context and Theories of Power. Journal of Sustainable Development, 9, 87.

Nabane, N., \& Matzke, G. (1997). A gender - sensitive analysis of a community - based wildlife utilization initiative in Zimbabwe's Zambezi valley. Society \& Natural Resources, 10, 519-535.

Ncube, G. (2011). Crisis of communal leadership: Post-colonial local government reform and administrative conflict with traditional authorities in the communal areas of Zimbabwe. African Journal of History and Culture, 3, 89-95.

North, D. (2003). The Role of Institutions in Economic Development. The Manchester School.

North, D. C. (1993). Institutional change: a framework of analysis. Institutional change: Theory and empirical findings 35-46.

Olson, M., \& Olson, M. (1965). The logic of collective action: public goods and the theory of groups. Harvard University Press.

Rihoy, E., Chirozva, C., \& Anstey, S. (2007). "People are not Happy" Speaking up for Adaptive Natural Resource Governance in Mahenye. Programme for Land and Agrarian Studies, 1-52.

Russell, A. J. M., \& Dobson, T. (2011). Chiefs as Critical Partners for Decentralized Governance of Fisheries: An Analysis of Co-Management Case Studies in Malawi. Society \& Natural Resources, 24, 734-750. http://dx.doi.org/10.1080/08941920.2010.501432

Saito-Jensen, M., Nathan, I., \& Treue, T. (2010). Beyond elite capture? Community- based natural resource management and power in Mohammed Nagar village, Andhra Pradesh, India. Environmental Conservation, $37,327-335$.

Sicilia, O. (n.d.). Oratory in mhondoro ritual spaces in northern Zimbabwe:-Traditional? authority, power 
relations and local political structures.

Taylor, R. (2009). Community based natural resource management in Zimbabwe: the experience of CAMPFIRE. Biodiversity and Conservation, 18, 2563.

Taylor, R., \& Murphree, M. W. (2007). Case Studies on Successful Southern African NRM Initiatives and their Impact on Poverty and Governance. Zimbabwe: Masoka and Gairezi.

Williamson, O. E. (2000). The New Institutional Economics: Taking Stock, Looking Ahead. Journal of Economic Literature, 38, 595-613.

Wong, S. (2010). Elite Capture or Capture Elites? Lessons from the "Counter-elite"and "Co-opt-elite"Approaches in Bangladesh and Ghana. Working Papers.

\section{Copyrights}

Copyright for this article is retained by the author(s), with first publication rights granted to the journal.

This is an open-access article distributed under the terms and conditions of the Creative Commons Attribution license (http://creativecommons.org/licenses/by/4.0/). 